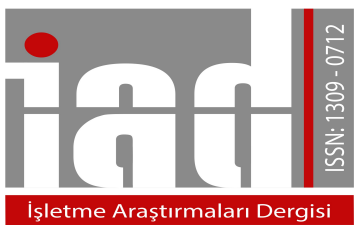

Journal Of

Business Research

Turk

www.isarder.org

\title{
Impact of Demographic Variables on Job Stress Factors: A Study on Turkish Employees
}

\author{
Oya TAMTEKIN AYDIN \\ İstanbul Bilgi University \\ School of Tourism and Hotel Management \\ İstanbul, Turkey \\ orcid.org/0000-0003-3695-0828 \\ oya.aydin@bilgi.edu.tr
}

\begin{abstract}
Pursuant to research regarding hotel management and tourism, several stress factors have been determined to affect both employees and managers. However, relevant literature does not adequately explore the effect of demographic variables on the stress factors. Moreover, no measurement has been identified to test job stress factors for Turkish hotel employees. Accordingly, this study, particularly aimed (a) to develop a scaling method for examining job stress factors for hotel employees in Turkey, and (b) to examine the differences between demographic characteristics and job stress factors obtained from the scaling endeavor. A convenience sampling method was used to determine the participants in the study. Then, face-to-face questionnaires were administered to employees at four- and five-star hotels in Istanbul. In total, 500 questionnaires were delivered to the employees, and 379 questionnaire forms were considered valid. At the end of the study, scaling was obtained that includes 33 items falling under six job stress factors, the factors of job stress and factor items were ranked and then, the differences between the demographic variables and job stress factors were presented.
\end{abstract}

Keywords: job stress factors, demographic factors, hotel employee.

\section{Introduction}

Job stress is a problem in the hospitality industry, just as it is in other businesses. Much of the relevant research (Ashton, 2017; Chan \& Dongyu, 2011; Lambert, Minor, Wells, \& Hogan, 2016; Hwang, Hyun, \& Park, 2013; Mansour \& Mohanna, 2017; Sunny'Hu \& Cheng, 2010; Tsaur \& Tang, 2012) indicates that the vast majority of employees experiences high levels of stress in their workplace, which can generate negative impacts on both the employee and the organization. Therefore, it is important to identify and understand the stressors experienced by employees in order to develop appropriate management methods (Law, Pearce, \& Woods, 1995). By examining 
relevant research on this issue that refers, generally, to the determinants of job-related stress, the kinds of stress can be linked to being mostly related to performance, turnover intention, or burnout, rather than relating it to demographic factors. However, certain constrained empirical studies examined the differences between demographic variables and job stress factors, especially for Turkish hotel employees. The significance of this study is two-fold. First, as there are not enough studies in Turkish literature regarding the job stress of hotel employees, there is no scaling to uncover their job stress factors. Second, hospitality literature tends to emphasize the relations between variables such as job or role stress, burnout, locus of control and job performance or attitudes (MurrayGibbons \& Gibbons, 2007), but the degree of employee stress based on demographic characteristics remains poorly understood (Chuang \& Lei, 2011). Therefore, this study aims to determine job stress factors for Turkish hotel employees, and to investigate the differences between the demographic variables and job stress factors.

\section{Literature Review}

Job stress is widespread within the hospitality industry (Kim, Shin, \& Umbreit, 2007; Papadopoulou-Bayliss, Ineson, \& Wilkie, 2001; Wildes, 2007), as it is labourintensive and involves frequent rotations, work overload, anti-social working hours, intensive contacts with customers, and highly emotional labour characteristics (Chiang, Birtch, \& Kwan, 2010; Hayes \&Weathington, 2007; Wong \&Huang, 2014). Therefore, even if the presence of stress at work is almost inevitable in all the organizations, to manage it in a right way is so important for all hotels like the other business areas. To control stress, the organizations usually begin by understanding job stress as a concept with its reasons and results.

Job stress can be defined as a psychological and physical strain that appears when a mismatch occurs between work demands and resources (Lazarus, 1993). In an organizational context, the term job stress is used interchangeably with work stress and occupational stress (AbuAlRub, 2004; Ismail, Mohamed, Sulaiman, Ismail, Z., \& Mahmood, 2010; Larson, 2004). It is a generic term that has been explained as a temporary adaptation process causing psychological strain; it is generally caused by an imbalance between work demands and one's capability to respond to the job, a combination that can eventually lead to job burnout (Rothmann, Jackson, \& Kruger, 2003). According to Chuang and Lei (2011) as one of the prevailing issues for today's workforce is job stress and it derives from people's reactions to the work environment and situations that appear threatening to them. Jamal and Baba (2000) study defined job stress as a poor fit between the individual abilities and the work environment in which either excessive demands are made on the individual or the individual is not fully equipped to handle a particular situation.

High levels of occupational stress have a negative impact on performance (AbuAlRub, 2004; Sullivan \& Bhagat, 1992). Stress at work can affect an organization with employee absenteeism, intention to leave, interpersonal difficulties, and poor performance (Ashton, 2017). Stress in the workplace, a common cause of job dissatisfaction (Golbasi, Kelleci, \& Dogan, 2008), positively correlates with employee burnout and voluntary turnover intention and negatively correlates with employee performance, productivity, and absenteeism (Chiang \& Liu, 2017; Jamal, 1990; Robbins, 2003). The study by McFillen, Riegel and Enz (1986) examined the reasons for restaurant managers' turnover. They indicated the issues of pay; treatment by 
supervisors; work hours; and job pressure as reasons for turnover and the study emphasized that these people who leave their job were experiencing stress of various forms. Research conducted in Tourism Training Australia by Marwick in 1991 outlined the reasons why employees left the tourism industry. This research identified three reasons and one of them was stress, the others were lack of understanding of industry work conditions and being too young to cope (especially in front-line positions). Woodruff (1993), found that the high levels of stress linked to serious negative outcomes such as social and family problems and decreased job performance. It also causes high rates of work absenteeism and burnout (Koç \& Bozkurt, 2017; Westman \& Etzion, 2001). High levels of job stress have been shown to be associated with a variety of negative consequences for employees in both the workplace and in their private lives, including physical illness and even mental disorders in extreme cases (Brewer \& McMahan-Landers, 2003; Ismail, Yao, \& Yunus, 2009). The researchers noted that job stress is negatively correlated to employees' task performance and organizational performance (Kaya, 2013). Overall, many studies (Abramis, 1994; AbuAlRub, 2004; Cleveland, O'Neill, Himelright, Harrison, Crouter, \& Drago, 2007; Jamal \& Baba, 2000; Leung, Chan, \& Dongyu, 2011; Savery \& Luks, 2001) have indicated the relationship between performance and job stress. They have especially uncovered that stress has been linked with the following three outcomes: reduced job satisfaction, lower organizational commitment, and increased turnover. Stress at work is a wellknown factor for low motivation and morale, decrease in performance, high turnover and sick-leave, accidents, low job satisfaction, low quality products and services, poor internal communication and conflicts (Murphy, 1995; Schabracq \& Cooper, 2000). Moreover, Chusmir and Franks (1988), said that all the problems in a business are related to stress and it has an effect on overall organizational efficiency and effectiveness. Research has shown a negative correlation between job stress and quality customer service delivery, that is, less stressed employees provide better customer service than more stressed ones (Beehr, Jex, Stacy, \& Murray, 2000; Varca, 1999). In general, work-related stress has been shown to result in declines in the quality of employee job performance (Gilboa, Shirom, Fried, \& Cooper, 2008), increases in exhaustion, decreases in employee ability to learn (Lepine, Podsakoff, \& Lepine, 2005), more depressive symptoms, hostility (Motowidlo, Packard, \& Manning, 1986), and withdrawal (Gupta \& Beeher, 1979). As a summary, within the hospitality industry like the other ones, work stress has been regarded as one of the most important issues facing managers and it affects the performance of all levels of employees, including both managers and employees (Ross, 1995).

As job stress is viewed as one of the most significant challenges facing organizations, many studies have tried to identify job stress factors. Cooper and Marshall (1976) classified stress into five categories: intrinsic to the job, resulting from one's role in the organization, career development, relationships with others, and organizational structure and climate. Ivancevich and Matteson (1980) suggested four main items that are namely: physical environment, individual level (role and career development variables), group level (relationship-based), and organizational level (organizational climate, structure, job design, and task characteristics). Schuler (1982) proposed seven categories of work stressors: job quality, relationships, organizational structure, physical quality, career development, change and role in the organization. Quick and Quick (1984) identified four factors as occupational stresses: task demands, role demands, physical demands, and interpersonal demands. Ross (1993) found that the 
major hospitality industry stressors were co-workers, pressure, working conditions and staff-guest interactions. Zohar (1994) stated four categories of occupational stress: conflict, role ambiguity, decision latitude and workload. In another study by Law et al. (1995), four particular job characteristics were identified, but not empirically confirmed, as contributing to stress: anti-social work hours; insufficient pay; poor management; requirement to deal with the public on a continuous day-to-day basis. Then, in their study, according to results, respondents felt that being very busy $(20 \%)$ and arrogant people (34\%) were important stressors in their job, but just over $65 \%$ of all respondents indicated that management was the chief source of stress in their work. Of the 61 respondents who mentioned management as a stressor, $28 \%$ gave lack of communication as an element of stress. Lack of recognition (17\%) and lack of interest (7\%) were other factors contributing to stress at work. Ramirez, Graham, Richards, Cull and Gregory (1996) said that the most significant sources of stress were work overload, feeling badly managed and resourced, managerial responsibilities and dealing with customers. Faulkner and Patiar (1997) determined six categories: factors intrinsic to the job, the management role, relationship with other people, career and achievement, organization structure and climate and home and work interface. Robbins (2003) suggested a model of stress that consists of three potential stressors, including environmental, organizational, and individual factors that cause a high level of job stress. Vakola and Nikolaou (2005) mentioned the following factors as occupational stress indicators: work relationships, work-life balance, overload, job security, control, resources and communication, pay and benefits, aspects of the job. Furthermore, Gibson, Ivancevich, Donnelly, and Konopaske (2006) suggested a model of organizational stress, comprising four levels: individual, group, organizational, and nonwork-related stress. A high level of job stress can occur at any of these levels. Mathur, Vigg, Sandhar, and Holani (2007) said that a number of job conditions frequently put employees under pressure and lead to stress. They outlined the following stress factors: Work overload, time deadlines, supervision, poor quality of supervision, role conflict and ambiguity, differences between company values and employee values, job itself, such as rotating shift work, machine-paced tasks, routine and repetitive work, long work hours, lack of perceived control, resource shortages, the demand for a large volume of error-free work, financial well-being and frustration about reaching the desired goal of employee. Kim, Lee, Y. H., and Lee, J. W. (2008) mentioned organizational job stress factors. They explained job stress items under 7 factors, including organizational factors, supervisors, compensation, colleagues/family, promotion/opportunities, job characteristics and organizational culture. Okutan and Tengilimoğlu (2002) and Baytar (2010) proposed similar factors to define the main items that cause job stress: the factors related with job, organizational role, career development, relationships with others, organization structure and climate, physical environment and environmental factors. In the study of Essawy (2016), job stressors are explained as role ambiguity, role conflict, role overload and interpersonal conflict. Overall, several studies have tried to explain forces at work that can contribute to the feeling of stress on employees. This study aims to determine job stress factors for investigating the differences between the demographic variables and these factors for Turkish employees. Thus, 6 hypotheses are proposed as follows:

$\mathbf{H}_{\mathbf{1}}$ The job stress factors differ due to gender.

$\mathbf{H}_{2}$ The job stress factors differ due to marital status. 
$\mathbf{H}_{3}$ The job stress factors differ due to age.

$\mathbf{H}_{4}$ The job stress factors differ due to tenure.

$\mathbf{H}_{5}$ The job stress factors differ due to the department.

$\mathbf{H}_{6}$ The job stress factors differ due to education level.

\section{Methodology}

\section{Research Design}

The descriptive research method is pretty much as its name indicates, describe the situations or phenomenon being studied, that is, it does not make accurate predictions, and do not determine cause and effect (Jackson, 2009). There are three main kinds of descriptive research methods: observational methods, case-study methods and survey methods. In this study, the survey method was preferred. Data were analysed based on the research objectives using various statistical analyses, including: (a) Cronbach's alpha was computed to measure the reliability of job stress scale, (b) factor analysis was conducted to examine the factor structures of the job-stress scale, and (c) descriptive statistics, including mean ranking comparison, was performed to examine items and factors on the job-stress scale that concerned hotel employees in Istanbul, (d) the data is not normally distributed according to Kolmogorov Smirnov test, instead of $t$-test and ANOVA, the non-parametric alternatives, Kruskal Wallis and Mann Withney U were conducted to determine the difference between the demographic profiles of employees and job-stress factors. Statistical significance was determined at $p<.05$ in analyses.

\section{Sampling}

Convenience sampling method was used to determine the participants in the study. It is a less rigorous technique, involving the selection of the most accessible subjects. Also, this method is the least costly to the researcher, in terms of time, effort and money. In this study, participants were selected from employees at four- and fivestar hotels as they have more institutional structure. The questionnaire was sent to the 172 hotels human resources departments to ask permission to conduct a survey, 52 of them answered. 11 of these gave an appointment for conducting our study's survey. For obtaining data, the support of general manager of each hotel was established first. After permission was provided by the general manager, participants were asked to complete a questionnaire distributed by the human resource director. A cover letter included the instruction to explain the purpose of this research; after completion of the survey, employees gave their questionnaire to the human resource department. A total of 500 questionnaires was delivered to the employees at four- and five-star hotels; 379 of the questionnaires were collected and used in this research.

\section{Measurement}

The questionnaire was used as an instrument for data collection. When designing the survey questions, closed-ended ones were favored. To prepare them, the relevant literature had to be reviewed first. The initial survey was prepared based on the review of the existing literature - especially the studies of Okutan and Tengilimoğlu (2002), Baytar (2010) and Zohar (1994), wherein 46 items were identified. Second, three academics and five hotel managers with knowledge about job stress issues of hotels were consulted. After a discussion with these academics and managers, a question form was devised based on their opinions. The survey was later amended according to consequent concerns, additional contributions, and 40 items that were determined to 
influence the job stress of hotel employees. Then, the survey was distributed to 30 employees before the actual study commenced. The employees were asked to identify any problems that they may have had with it. Finally, the questionnaire of the study consisted of 40 close-ended questions and 6 demographic variable questions, this means that it is comprised of two parts. The first part consisted of six demographic variables questioning employee gender, marital status, age (5 options), tenure (4 options), department (11 options), and education level (5 options). The second part of the questionnaire contained 40 questions based on the existing literature and expert views. These determinants were measured on a five-point Likert-type scale, with responses ranging from 1 (more stressful) to 5 (less stressful). Factor analysis was then performed to the second part of the questionnaire including 40 items by using the Principal Component and Varimax Rotation techniques. A total of 7 items were excluded because they did not contribute to a simple factor structure and failed to meet a minimum criterion of having a primary factor loading of .3 (Çokluk, Şekercioğlu and, Büyüköztürk, 2014; Loewen and Gonulal, 2015; Uslu, 2016). Thus, the second part of the questionnaire had 33 questions reflecting the most important items on hotel employee job stress. At the end of the factor analysis, the scale had 6-factorial structure with 33 items, and explains $57.4 \%$ of variance for job stress. Reliability analyses were conducted to ensure the reliability and internal consistency of the questionnaire. The reliability coefficient was $\alpha=.90$ for the whole scale, and $\alpha=.66-.87$ for its dimensions, confirming that inter-correlations among the test subscales are high. Itemtotal correlations for each item in Factor 1 are $r=.53-.65$; in Factor 2 are $r=.52-.77$; in Factor 3 are $r=.46-.52$, in Factor 4 are $r=.53-.68$; in Factor 5 are $r=.51-.62$ and in Factor 6 are $\mathrm{r}=.45-.49$. Item-total correlations $(\mathrm{r}) \geq .30$ are evidence for the validity of items in the scale (Çokluk et al. 2014; Hof, 2012). In this regard, all items in the scale can measure in the same construct. As a result, this survey is a valid and reliable data collection instrument to measure job stress of hotel Turkish employees.

\section{Results}

\section{Distribution of the Demographic Variables}

According to the descriptive statistics, 129 of the respondents were female (34\%) and 250 were male $(66 \%) ; 145$ were married $(38.3 \%)$ and 234 were single $(61.7 \%)$. Nearly half of the respondents were aged between 26 and 35; the percentage of employees over 56 years of age was smaller than the others. The majority of the employees had worked in the tourism industry for between 1 and 10 years (315 employees, 83.2\%). The largest percentage of respondents worked in the front office, and front-office employees accounted for nearly half of the respondents (179 employees, 47.2\%). The percentages of other groups are shown in Table 1. A few of the respondents had master's degrees (9 employees, $2.4 \%$ ). Table 1 presents the results of the demographic analysis. 
Table 1 Description of the respondents $(n=379)$

\begin{tabular}{|c|c|c|}
\hline & Frequency & Percentage \\
\hline \multicolumn{3}{|l|}{ Gender } \\
\hline Male & 250 & 66 \\
\hline Female & 129 & 34 \\
\hline \multicolumn{3}{|l|}{ Marital status } \\
\hline Married & 145 & 38.3 \\
\hline Single & 234 & 61.7 \\
\hline \multicolumn{3}{|l|}{ Age } \\
\hline $16-25$ & 99 & 26.1 \\
\hline $26-35$ & 191 & 50.4 \\
\hline $36-45$ & 73 & 19.3 \\
\hline $46-55$ & 13 & 3.4 \\
\hline$>56$ & 3 & 0.8 \\
\hline \multicolumn{3}{|l|}{ Tenure } \\
\hline $0-5$ & 112 & 29.6 \\
\hline $6-10$ & 203 & 53.6 \\
\hline $11-15$ & 48 & 12.7 \\
\hline$>16$ & 16 & 4.3 \\
\hline \multicolumn{3}{|l|}{ Department } \\
\hline Restaurant & 64 & 16.9 \\
\hline Spa & 2 & 0.5 \\
\hline Human resource & 8 & 2.1 \\
\hline Front-office & 179 & 47,2 \\
\hline Kitchen & 21 & 5.5 \\
\hline Accounting & 14 & 3.7 \\
\hline House-keeping & 27 & 7.1 \\
\hline Sales-Marketing & 11 & 2.9 \\
\hline Security & 22 & 5.8 \\
\hline Bar & 16 & 4.2 \\
\hline Others & 15 & 4 \\
\hline \multicolumn{3}{|l|}{ Education } \\
\hline Primary School & 43 & 11.30 \\
\hline High School & 116 & 30.60 \\
\hline Vocational & 88 & 23.20 \\
\hline Bachelor's degree & 123 & 32.50 \\
\hline Master's degree & 9 & 2.40 \\
\hline
\end{tabular}

\section{Findings of Factor and Descriptive Analysis}

Before testing the factor structure of the scale, the sufficiency of respondent numbers for factor analysis was checked, and 379 respondents within the data set of pilot questionnaire were found enough for proceeding to explanatory factor analysis according to the general rule "there should be at least 5 subjects per variable and a total of no fewer than 100 subjects" (Bryman and Cramer, 1990, as cited in Cohen, Manion, and Morrison, 2007, p. 563). As the first step of EFA, the adequacy of sampling and suitability of the data set in all groups for EFA was assessed by Kaiser-Meyer-Olkin 
(KMO) and Bartlett's Test of Sphericity (BTS). For this scale, KMO value was .922 and BTS $(\chi 2=5813.07, p=.00)$ showed a significant result. The researcher, based on the findings of KMO and BTS, decided that data set of the survey is suitable to perform explanatory factor analysis. Explanatory factor analysis was then performed by using Principal Component and Varimax Rotation techniques. As a result of this analysis, factor loadings and common factor variances for each item were found, as presented in Table 2.

Table 2 Factor Analyses for Stress Items

\begin{tabular}{|c|c|c|c|c|c|c|c|}
\hline No & Constructs and items & $\mathbf{M}$ & S.D. & $\begin{array}{c}\text { Factor } \\
\text { loadings }\end{array}$ & $\begin{array}{l}\text { Eigen } \\
\text { value }\end{array}$ & $\begin{array}{c}\text { Cronbach's } \\
\text { alpha }\end{array}$ & $\begin{array}{c}\text { Explain } \\
\text { Variance } \\
(\%)\end{array}$ \\
\hline & Factor 1 & 3.09 & .74 & & 11.237 & .874 & 34.05 \\
\hline I23 & Employees are not appreciated by a superior & 2.95 & 1.28 & .675 & & & \\
\hline $\mathrm{I} 21$ & The work I do is ignored by others & 2.84 & 1.30 & .654 & & & \\
\hline $\mathrm{I} 24$ & $\begin{array}{l}\text { Employees fail to receive personal support } \\
\text { from colleagues }\end{array}$ & 3.32 & 1.19 & .642 & & & \\
\hline $\mathrm{I} 22$ & $\begin{array}{l}\text { There are disputes and problems arising in } \\
\text { relationships with superiors }\end{array}$ & 2.84 & 1.35 & .638 & & & \\
\hline I19 & $\begin{array}{l}\text { Failure to provide the professional aspects of } \\
\text { self-development opportunities }\end{array}$ & 2.91 & 1.19 & .608 & & & \\
\hline I26 & $\begin{array}{l}\text { Ambition is rising among employees and } \\
\text { related issues are also increasing as a result of } \\
\text { competition }\end{array}$ & 2.78 & 1.31 & .550 & & & \\
\hline $\mathrm{I} 20$ & $\begin{array}{l}\text { Unfair and unbalanced promotion opportunities } \\
\text { are seen }\end{array}$ & 2.75 & 1.31 & .549 & & & \\
\hline \multirow[t]{2}{*}{$\mathrm{I} 25$} & Gossip in workplace & 2.33 & 1.32 & .499 & & & \\
\hline & Factor 2 & 3.18 & .90 & & 1.99 & .846 & 6.031 \\
\hline I33 & Excessive discipline and pressure & 3.11 & 1.27 & .773 & & & \\
\hline $\mathrm{I} 34$ & Having to give vital decisions & 3.35 & 1.15 & .740 & & & \\
\hline $\mathrm{I} 32$ & Strict control and supervision are felt & 3.08 & 1.27 & .732 & & & \\
\hline $\mathrm{I} 35$ & A feeling of being restrained while working & 3.17 & 1.30 & .640 & & & \\
\hline \multirow[t]{2}{*}{$\mathrm{I} 37$} & Political pressure & 3.61 & 1.28 & .524 & & & \\
\hline & Factor 3 & 2.84 & 1.02 & & 1.722 & .771 & 5.219 \\
\hline I5 & The workplace is crowded and noisy & 3.31 & 1.26 & .671 & & & \\
\hline I6 & $\begin{array}{l}\text { Poor temperature and lighting characterize the } \\
\text { work environment }\end{array}$ & 3.52 & 1.28 & .667 & & & \\
\hline I4 & Work is monotonous & 3.21 & 1.22 & .648 & & & \\
\hline $\mathrm{I} 3$ & Long working hours & 3.07 & 1.23 & .563 & & & \\
\hline I9 & $\begin{array}{l}\text { Having to finish work at a certain time is } \\
\text { forced }\end{array}$ & 3.23 & 1.26 & .522 & & & \\
\hline I12 & $\begin{array}{l}\text { The lack of space to relax in the working } \\
\text { environment }\end{array}$ & 3.16 & 1.39 & .511 & & & \\
\hline \multirow[t]{2}{*}{ I7 } & Frequent shift changes & 2.94 & 1.40 & .486 & & & \\
\hline & Factor 4 & 2.96 & .91 & & 1.573 & .823 & 4.765 \\
\hline I29 & To have different views from management & 3.20 & 1.30 & .720 & & & \\
\hline $\mathrm{I} 30$ & $\begin{array}{l}\text { Unable to get support from executives during } \\
\text { decision processes }\end{array}$ & 2.99 & 1.31 & .705 & & & \\
\hline $\mathrm{I} 31$ & Inability to join the decision-making process & 3.07 & 1.19 & .673 & & & \\
\hline $\mathrm{I} 28$ & I work in an unreliable environment & 3.21 & 1.38 & .477 & & & \\
\hline $\mathrm{I} 36$ & I am unable to criticize managerial practices & 3.17 & 1.23 & .419 & & & \\
\hline
\end{tabular}


Factor 5

I16 The inability to work in one's desired field

I feel that organizational objectives and

I17 policies are not well performed.

I feel uninformed except for my own duties

because otherwise, I am excluded.

I15 The possibility of making mistakes at work

I14 Imbalance in the duties and authorities

\section{Factor 6}

$\mathrm{I} 40$

The inability to spend enough time with family and friends

I39

The economic and political conditions of the country

The negative effect of family affairs on work life weighs on me.

$\begin{array}{lccccc}\mathbf{3 . 1 5} & \mathbf{. 9 0} & & \mathbf{1 . 2 5 9} & \mathbf{. 8 0 2} & \mathbf{3 . 8 1 4} \\ 3.53 & 1.26 & .733 & & & \\ 3.48 & 1.29 & .643 & & & \\ & & & & & \\ 3.36 & 1.33 & .560 & & & \\ 3.19 & 1.18 & .551 & & \mathbf{3 . 5 2 1} \\ 2.70 & 1.32 & .420 & & & \\ \mathbf{3 . 1 3} & . \mathbf{8 9} & & \mathbf{1 . 1 6 2} & \mathbf{. 6 6} & \\ 2.51 & 1.30 & .699 & & & \\ 2.89 & 1.29 & .641 & & & \\ 3.20 & 1.40 & .633 & & & \end{array}$

1.259

.802

814
As shown in Table 2, the first factor is composed of 8 items with .499-.675 factor loadings and can explain $34.05 \%$ of the variance (11.237 Eigen Value). The second factor had 5 items which had .524-.773 factor loadings can explain $6.031 \%$ of the variance (1.99 Eigen Value). The third factor consisted of 7 items with .486-.671 factor loadings which can explain 5.219\% (1.722 Eigen Value). The fourth factor consisted of 5 items with .419-.72 factor loadings which can explain $4.765 \%$ (1.573 Eigen Value). The fifth factor consisted of 5 items with $.42-.733$ factor loadings which can explain $3.814 \%$ (1.259 Eigen Value). The sixth factor consisted of 3 items with .633-.699 factor loadings which can explain 3.521\% (1.162 Eigen Value). In conclusion, the scale had a 6 -factorial structure within 33 items and can explain $57.401 \%$ of the variance for effective job stress factors on a hotel employee. Table 2 also includes descriptive statistics. A five-point Likert scale ( $1=$ more stressful to $5=$ less stressful) was used to interpret responses. According to the perception of respondents, Factor 3 was the most important, with a score of 2.84; Factor 2 was the least important, with a score of 3.18. In addition, the hotel employees ranked "gossip in the workplace" and "the inability to spend enough time with family and friends" as the most stressful items; dealing with "political pressure issues" and "the inability to work in one's desired field" were the least stressful items.

\section{Testing Hypothesis}

Before applying the analysis, tests for normality were performed. Based on the basic assumption of parametric analysis of variance, the data should be normally distributed. According to the normality test results, the probabilities are greater than 0.05 , so we accept that these data are not different from normal. As the data are not normally distributed according to Kolmogorov Smirnov Test (p-value of all 6 factors are less than 0.05), instead of t-test and ANOVA, the non-parametric alternatives, Kruskal Wallis and Mann Withney U were used testing hypotheses.

\section{Effects of Gender}

To state the difference between gender and the employees' stress, Mann-Whitney U test was performed. According to the related statistics that are shown in Table 3, Factor 3 differed by gender. In addition, the results of the mean rank in Table 3 refer 
that female hotel employee placed more emphasis on these four stress factors (Factor 1, 2, 3 and 4) than male hotel employee. The male hotel employee placed more emphasis on Factor 5 and 6.

Table 3 Gender (Mann-Whitney $U$ )

\begin{tabular}{|c|c|c|c|c|}
\hline & & $N$ & Mean Rank & $Z$ \\
\hline \multirow{2}{*}{ Factor 1} & Male & 250 & 196,50 & \multirow{2}{*}{$-1,608$} \\
\hline & Female & 129 & 177,41 & \\
\hline \multirow{2}{*}{ Factor 2} & Male & 250 & 197,84 & \multirow{2}{*}{$-1,943$} \\
\hline & Female & 129 & 174,81 & \\
\hline \multirow{2}{*}{ Factor 3} & Male & 250 & 198,64 & \multirow{2}{*}{$-2,144^{a}$} \\
\hline & Female & 129 & 173,26 & \\
\hline \multirow{2}{*}{ Factor 4} & Male & 250 & 192,04 & \multirow{2}{*}{,- 507} \\
\hline & Female & 129 & 186,04 & \\
\hline \multirow{2}{*}{ Factor 5} & Male & 250 & 189,23 & \multirow{2}{*}{,- 192} \\
\hline & Female & 129 & 191,50 & \\
\hline \multirow[b]{2}{*}{ Factor 6} & Male & 250 & 188,36 & \multirow{2}{*}{,- 407} \\
\hline & Female & 129 & 193,17 & \\
\hline
\end{tabular}

${ }^{a}$ Group means are significantly different in 95\% level $(p<0.05)$

\section{Effects of Marital Status}

To state the difference between marital status and the employees' stress, MannWhitney $U$ test was performed. The related statistics are shown in Table 4. This test showed that 2 out of 6 factors showed the difference. Employees differed by marital status in their evaluation of Factor 1 and Factor 3. Moreover, the results in Table 4 refer that the single hotel employee placed more emphasis on these six stress factors than the married hotel employee.

Table 4 Marital Status (Mann-Whitney U)

\begin{tabular}{|c|c|c|c|c|}
\hline & & $N$ & Mean Rank & $Z$ \\
\hline \multirow{2}{*}{ Factor 1} & Married & 145 & 204,19 & \multirow{2}{*}{$-2,052^{a}$} \\
\hline & Single & 234 & 180,46 & \\
\hline \multirow{2}{*}{ Factor 2} & Married & 145 & 203,40 & \multirow{2}{*}{$-1,944$} \\
\hline & Single & 234 & 180,94 & \\
\hline \multirow{2}{*}{ Factor 3} & Married & 145 & 211,77 & \multirow{2}{*}{$-3,118^{a}$} \\
\hline & Single & 234 & 175,79 & \\
\hline \multirow{2}{*}{ Factor 4} & Married & 145 & 202,02 & \multirow{2}{*}{$-1,751$} \\
\hline & Single & 234 & 181,80 & \\
\hline \multirow{2}{*}{ Factor 5} & Married & 145 & 198,12 & \multirow{2}{*}{$-1,204$} \\
\hline & Single & 234 & 184,20 & \\
\hline \multirow{2}{*}{ Factor 6} & Married & 145 & 198,76 & \multirow{2}{*}{$-1,297$} \\
\hline & Single & 234 & 183,80 & \\
\hline
\end{tabular}

${ }^{a}$ Group means are significantly different in 95\% level $(p<0.05)$

\section{Effects of Age}

To determine the difference between age and the employees' stress, KruskalWallis test was performed in Table 5. As seen in Table 5, the results of the KruskalWallis test showed Factor 2 out of 6 factors had mean scores differing statistically between (at least two) different age groups. In addition, that the following results in 
Table 5 refer that hotel employee who is between 46-55 years old, place more emphasis on these six stress factors than others, with the exception of Factor 2 and Factor 5. A hotel employee who is between 26-35 years old, place more emphasis on these two stress factors. The results show that the effects of stress factors were seen least in the age groups are greater than 56 in all six factors.

Table 5 Age (Kruskal-Wallis Test)

\begin{tabular}{|c|c|c|c|c|}
\hline & Age & $N$ & Mean Rank & Chi-Square \\
\hline \multirow[t]{5}{*}{ Factor 1} & $16-25$ & 99 & 207,72 & 4,92 \\
\hline & $26-35$ & 191 & 181,97 & \\
\hline & $36-45$ & 73 & 185,97 & \\
\hline & $46-55$ & 13 & 180,46 & \\
\hline & $>56$ & 3 & 256,33 & \\
\hline \multirow{5}{*}{ Factor 2} & $16-25$ & 99 & 213,35 & $16,529^{\mathrm{a}}$ \\
\hline & $26-35$ & 191 & 171,91 & \\
\hline & $36-45$ & 73 & 201,05 & \\
\hline & $46-55$ & 13 & 180,42 & \\
\hline & $>56$ & 3 & 343,83 & \\
\hline \multirow[t]{5}{*}{ Factor 3} & $16-25$ & 99 & 192,37 & 8,087 \\
\hline & $26-35$ & 191 & 183,23 & \\
\hline & $36-45$ & 73 & 199,19 & \\
\hline & $46-55$ & 13 & 182,04 & \\
\hline & $>56$ & 3 & 353,5 & \\
\hline \multirow[t]{5}{*}{ Factor 4} & $16-25$ & 99 & 194,78 & 7,607 \\
\hline & $26-35$ & 191 & 181,83 & \\
\hline & $36-45$ & 73 & 202,16 & \\
\hline & $46-55$ & 13 & 172,38 & \\
\hline & $>56$ & 3 & 332,67 & \\
\hline \multirow[t]{5}{*}{ Factor 5} & $16-25$ & 99 & 201,96 & 7,729 \\
\hline & $26-35$ & 191 & 177,46 & \\
\hline & $36-45$ & 73 & 199,88 & \\
\hline & $46-55$ & 13 & 201,19 & \\
\hline & $>56$ & 3 & 305 & \\
\hline \multirow[t]{5}{*}{ Factor 6} & $16-25$ & 99 & 192,2 & 2,029 \\
\hline & $26-35$ & 191 & 188,27 & \\
\hline & $36-45$ & 73 & 189,5 & \\
\hline & $46-55$ & 13 & 181,62 & \\
\hline & $>56$ & 3 & 276 & \\
\hline
\end{tabular}

${ }^{a}$ Significant in $95 \%$ level $(d f=4, p<0.05)$

\section{Effects of Tenure}

To determine the difference between tenure and the employees' stress, KruskalWallis test was performed. As seen in Table 6, the results of the Kruskal-Wallis test showed Factor 1 out of 6 factors had mean scores differing statistically between (at least two) different tenure groups. As seen in Table 6, the hotel employees who work on its job more than 16 years placed more emphasis on Factor 4, 5 and 6 than others, they placed less emphasis on Factor 3. Factor 1 and 2 create job stress, especially for employees who work on its job more 11-15 years. Factor 3 creates job stress especially for employees who work on its job more 6-10 years. 
O. Tamtekin Aydın 10/2 (2018) 803-826

Table 6 Tenure (Kruskal-Wallis Test)

\begin{tabular}{lcccc}
\hline & Tenure & $N$ & Mean Rank & Chi-Square \\
\hline \multirow{4}{*}{ Factor 1 } & $1-5$ & 112 & 196,05 & \\
& $6-10$ & 203 & 196,1 & $8,982^{\mathrm{a}}$ \\
& $11-15$ & 48 & 145,41 & \\
Factor 2 & $>16$ & 16 & 192,37 & \\
& $1-5$ & 112 & 198,1 & \\
& $6-10$ & 203 & 189,09 & 1,752 \\
Factor 3 & $11-15$ & 48 & 174,54 & \\
& $>16$ & 16 & 178,63 & \\
& $1-5$ & 112 & 196,32 & \\
Factor 4 & $6-10$ & 203 & 182,53 & \\
& $11-15$ & 48 & 198,57 & \\
& $>16$ & 16 & 203,9 & \\
& $1-5$ & 112 & 182,77 & \\
Factor 5 & $6-10$ & 203 & 191,89 & \\
& $11-15$ & 48 & 198,53 & \\
& $>16$ & 16 & 178,57 & \\
\hline \multirow{4}{*}{ Factor 6 } & $1-5$ & 112 & 192,17 & \\
& $6-10$ & 203 & 190,28 & 1,522 \\
& $11-15$ & 48 & 190,54 & \\
\hline
\end{tabular}

\section{Effects of Department}

To determine the difference between a department and the employees' stress, Kruskal-Wallis test was performed. According to the results of the Kruskal-Wallis test statistics in Table 7, 2 of the 6 factors had score means that differed statistically between (at least two) different departments: Factor 1 and Factor 3. The mean rank results in Table 7 showed that Factor 1 and 3 had an important impact on kitchen employee, they had the least impact on human resources department. Factor 2 had an important impact on accounting department, it had the least impact on SPA department. Factor 4 had an important impact on sales marketing department, it has the least impact on SPA department. Factor 5 and 6 have an important impact on sales marketing department, they had the least impact on human resources department. 
O. Tamtekin Aydın 10/2 (2018) 803-826

Table 7 Department (Kruskal-Wallis Test)

\begin{tabular}{|c|c|c|c|c|}
\hline & Department & $N$ & Mean Rank & Chi-Square \\
\hline \multirow{11}{*}{ Factor 1} & Restaurant & 64 & 185,84 & \multirow{11}{*}{$25,253^{\mathrm{a}}$} \\
\hline & Spa & 2 & 227,75 & \\
\hline & Human resource & 8 & 273,06 & \\
\hline & Front-office & 179 & 180,03 & \\
\hline & Kitchen & 21 & 150,74 & \\
\hline & Accounting & 14 & 198,64 & \\
\hline & House-keeping & 27 & 164,81 & \\
\hline & Sales-Marketing & 11 & 166,64 & \\
\hline & Security & 22 & 256,77 & \\
\hline & Bar & 16 & 240,75 & \\
\hline & Others & 15 & 234,67 & \\
\hline \multirow{11}{*}{ Factor 2} & Restaurant & 64 & 194,15 & \multirow{11}{*}{11,250} \\
\hline & Spa & 2 & 347,75 & \\
\hline & Human resource & 8 & 241,81 & \\
\hline & Front-office & 179 & 179,36 & \\
\hline & Kitchen & 21 & 194,29 & \\
\hline & Accounting & 14 & 159,25 & \\
\hline & House-keeping & 27 & 193,41 & \\
\hline & Sales-Marketing & 11 & 190,41 & \\
\hline & Security & 22 & 220,07 & \\
\hline & Bar & 16 & 208,94 & \\
\hline & Others & 15 & 202,53 & \\
\hline \multirow{11}{*}{ Factor 3} & Restaurant & 64 & 181,56 & \multirow{11}{*}{$21,604^{\mathrm{a}}$} \\
\hline & Spa & 2 & 285 & \\
\hline & Human resource & 8 & 305,19 & \\
\hline & Front-office & 179 & 179,52 & \\
\hline & Kitchen & 21 & 156,93 & \\
\hline & Accounting & 14 & 181,57 & \\
\hline & House-keeping & 27 & 204,74 & \\
\hline & Sales-Marketing & 11 & 176,95 & \\
\hline & Security & 22 & 242,48 & \\
\hline & Bar & 16 & 207,47 & \\
\hline & Others & 15 & 218,53 & \\
\hline \multirow{11}{*}{ Factor 4} & Restaurant & 64 & 170,28 & \multirow{11}{*}{14,635} \\
\hline & Spa & 2 & 278,25 & \\
\hline & Human resource & 8 & 272,94 & \\
\hline & Front-office & 179 & 185,47 & \\
\hline & Kitchen & 21 & 180,02 & \\
\hline & Accounting & 14 & 205,54 & \\
\hline & House-keeping & 27 & 192,37 & \\
\hline & Sales-Marketing & 11 & 147,55 & \\
\hline & Security & 22 & 219,98 & \\
\hline & Bar & 16 & 218,91 & \\
\hline & Others & 15 & 223,77 & \\
\hline \multirow{4}{*}{ Factor 5} & Restaurant & 64 & 187,48 & \multirow{4}{*}{14,940} \\
\hline & Spa & 2 & 230 & \\
\hline & Human resource & 8 & 269,69 & \\
\hline & Front-office & 179 & 180,34 & \\
\hline
\end{tabular}




\begin{tabular}{|c|c|c|c|c|}
\hline & Kitchen & 21 & 209,71 & \\
\hline & Accounting & 14 & 211,32 & \\
\hline & House-keeping & 27 & 194,28 & \\
\hline & Sales-Marketing & 11 & 116,55 & \\
\hline & Security & 22 & 226,16 & \\
\hline & Bar & 16 & 206,09 & \\
\hline & Others & 15 & 196,63 & \\
\hline \multirow{11}{*}{ Factor 6} & Restaurant & 64 & 188,95 & \multirow{11}{*}{10,685} \\
\hline & Spa & 2 & 229,75 & \\
\hline & Human resource & 8 & 271,44 & \\
\hline & Front-office & 179 & 178,54 & \\
\hline & Kitchen & 21 & 214,52 & \\
\hline & Accounting & 14 & 193,54 & \\
\hline & House-keeping & 27 & 195,8 & \\
\hline & Sales-Marketing & 11 & 156,55 & \\
\hline & Security & 22 & 214,3 & \\
\hline & Bar & 16 & 202,41 & \\
\hline & Others & 15 & 210,03 & \\
\hline
\end{tabular}

${ }^{a}$ Significant in $95 \%$ level $(d f=10, p<0.05)$

\section{Effects of Education Level}

To determine the difference between a department and the employees' stress, Kruskal-Wallis test was performed. As seen in Table 8, the results of the KruskalWallis test showed that 2 out of 6 factors had score means that differed statistically between (at least two) different educational levels. Factor 2 and Factor 4 differed significantly by educational level. The mean rank results in Table 8 show that while the Factor 1, 2 and 3 had an important impact on master's degree, they have the least impact on primary school leavers. Factor 4 has an important impact on the vocational degree, it had the least impact on primary school leavers. Factor 5 and 6 an important impact on high school degree, they have the least impact on primary school leavers.

Table 8 Education Level (Kruskal-Wallis Test)

\begin{tabular}{llccc}
\hline \multicolumn{1}{c}{ Education level } & $N$ & Mean Rank & $\begin{array}{c}\text { Chi- } \\
\text { Square }\end{array}$ \\
\hline Factor 1 & Primary & 13 & 201.38 & \\
& High school & 116 & 178.85 & \\
& Vocational & 88 & 183.90 & 2,601 \\
& Bachelor's degree & 123 & 199.13 & \\
& Master degree & 9 & 177.20 & \\
\hline Factor 2 & Primary & 13 & 246.69 & \\
& High school & 116 & 187.43 & \multirow{10}{*}{ Vocational } \\
& Bachelor's degree & 88 & 191.51 & \\
& Master degree & 123 & 196.94 & \\
\hline Factor 3 & Primary & 9 & 164.71 & \\
& High school & 13 & 241.96 & \\
& Vocational & 116 & 188.13 & \\
& Bachelor's degree & 88 & 182.96 & 8,555 \\
& Master degree & 123 & 201.89 & \\
\hline
\end{tabular}




\begin{tabular}{|c|c|c|c|c|}
\hline \multirow[t]{5}{*}{ Factor 4} & Primary & 13 & 242.58 & \multirow{5}{*}{10,886} \\
\hline & High school & 116 & 176.13 & \\
\hline & Vocational & 88 & 172.26 & \\
\hline & Bachelor's degree & 123 & 209.36 & \\
\hline & Master degree & 9 & 177.17 & \\
\hline \multirow[t]{5}{*}{ Factor 5} & Primary & 13 & 246.73 & \multirow{5}{*}{7,588} \\
\hline & High school & 116 & 165.67 & \\
\hline & Vocational & 88 & 178.99 & \\
\hline & Bachelor's degree & 123 & 199.57 & \\
\hline & Master degree & 9 & 179.94 & \\
\hline \multirow[t]{5}{*}{ Factor 6} & Primary & 13 & 232.15 & \multirow{5}{*}{6,41} \\
\hline & High school & 116 & 160.88 & \\
\hline & Vocational & 88 & 183.31 & \\
\hline & Bachelor's degree & 123 & 200.20 & \\
\hline & Master degree & 9 & 178.12 & \\
\hline
\end{tabular}

${ }^{a}$ Significant in $95 \%$ level $(d f=4, p<0.05)$

\section{Conclusion}

Two goals were established in this study: (1) to develop a scale related to the job stress of hotel employees and (2) to investigate the differences between "gender, marital status, age, tenure, department, education level" and "job stress factors." The first goal required that data be collected from 30 hotel employees in Istanbul by using the pilot version of the scale. According to exploratory factor analysis, the scale has a 6 -factorial structure and explains $57.4 \%$ of the variance for job stress factors for hotel employees. The reliability coefficient was $\alpha=.92$ for the whole scale and $\alpha=.42-.77$ for its 33 items. The structural model of the scale was also tested by a confirmatory factor analysis with the secondary data set that was collected from other 379 employees, and the 6-factorial structure was confirmed. As a result, this scale was accepted as a valid and reliable data collection instrument that adequately measures job stress among hotel employees.

A descriptive analysis of stress factors was performed next. The results showed that Factor 3 was the most important, while Factor 2 was least important according to respondents. Workplace gossip and the inability to spend enough time with family and friends were the most important stressors per the perception of respondents. Political pressure and the inability to work in one's desired field were the least important stress factors. Parallel to our study, many studies have shown that gossip decreases productivity, erodes morale, damages feelings, harms reputations, and increases stress (Danziger, 1988; Michelson \& Mouly, 2000). Gossip could also indicate low trust, burnout, hostile relationships, and infrequent contact with managers (Ellwardt, Labianca, \& Wittek, 2012). Georganta, Panagopoulou, \& Montgomery (2014) stated that gossip is positively related to emotional exhaustion and depersonalization such as job stress. Traditionally, gossip has been viewed negatively and needs to be minimized in the context of the organization, if not eliminated completely. One of the most observable negative effects of gossip is the damage it causes to relationships and to the reputations of those affected and their stature in the workplace (Kurland \& Pelled, 2000). Employees considered the inability to spend enough time with family and friends an important factor contributing to job stress, which suggests the need for work-life balance. Many studies have supported the importance of work-life balance for employees (Chiang, Birtch, \& Kwan, 2010; Wong \& Ko, 2009). Consistent with our 
research, Sutton and Rafaeli (1987) noted that when employees focus on their work, they are bothered less by interferences from the physical environment. Particularly when the employees are busy, they are less likely to notice their working environment, and thus less likely to have time to notice noise, heat, and poor lighting. Therefore, such stressors are less likely to influence them. As a summary, nowadays, maintaining a work-life balance is an important issue among employees. Hotel management needs to develop more appropriate policies and schemes to handle their "internal customers," as the quality of service for hotel guests depends on them. Hotel managers should not forget that their employees are a crucial component of a hotel's competitive edge (Wong and Huang, 2014).

This study also sheds light on the differences between demographic factors and job stress factors. In some previous studies (Chang and Kim, 2014; Hwang, Lee, Park, Chang, and Kim, 2014; Sunny'Hu and Cheng, 2010; Torkelson, Muhonen, and Peiró, 2007), the differences between demographic factors (gender, age, department, marital status, education level, and length of employment) and job stress factors were examined. Wilnefield and Anstey (1991) said that up to one-third of the respondents reported significant levels of job stress, which vary by age and gender as well as by attitudes toward general practices. The results of our analyses showed that Factor 3 varied by gender. Law et al. (1995) indicated that a difference between males and females is present in the type of stress experienced. Male respondents indicated more stress related to organizational processes such as performance, committing mistakes, and job security, while females recorded higher frequencies for stress relating to role characteristics such as conflicting duties, lack of assistance, and confusion with the service. Baytar (2010) found no statistical gender differences in stress factors. A study by Agyemang and Arkorful (2013) also emphasized that in terms of gender, males and females did not differ with respect to job stress.

Furthermore, the results of our study show that female hotel employees placed more emphasis on some of the aforementioned stress factors more than males. Parallel to our study, Cozens (1998) and Wilnefield and Anstey (1991) demonstrated that the outcomes of job stress have a higher impact on females than on males. De Smet et al. (2005) claimed that job stress prevalence was significantly higher in women. Klassen and Chiu (2010) found that female teachers experienced greater stress (from both workload and student behaviors during class) in classroom management. Similarly, De Smet et al. (2005) stated that job strain is slightly higher among women. However, Cooper, Rout, and Faragher (1989) found that males in general have higher rates of job stress. However, O'Neill and Davis (2011) said that there are no significant differences by gender.

Our analysis indicated that employees differed by marital status in their evaluation of Factor 1 and Factor 3. Although some prior research suggests that married employees tend to experience different types and levels of stress than unmarried employees (Kessler, 1979; Thoits, 1987), our mean ranks show that all factors caused more stress for single employees. Consistent with the results of our study's mean ranks, Krone, Tabacchi and Faber (1988) found that single women suffered the most, while married respondents suffered the least. The study of Elkahlout and Algaed (2003) outlined that there is no difference based on marital status with regard to the answers given to job stress questions. Similar to their study, O’Neill and Davis (2011) said that no significant differences were discovered between married and unmarried employees based on work 
stressors. Hwang, Hyun and Park (2013) indicated that single employees were stressed more by conflicts with job responsibility than married employees; married employees suffered more from companies' work and pay practices than single employees. However, some studies (Preston, 1995; Vanagas, Bihari-Axelsson, and Vanagiene, 2004) found that married women were more vulnerable to stress. Agyemang and Arkorful (2013) also approved this view and they concluded that married women reported higher levels of stress than single women.

Our findings revealed that Factor 2 (out of six factors) had score means statistically different between (at least two) different age groups. These findings paralleled those of Baytar (2010). Her study posited a relationship between age and stress factors related to organizational structure and management, such as responsibilities with roles and their density, imbalance between responsibility and authority, and a feeling that organizational objectives and policies are not well performed. Pocnet, Antonietti, Massoudi, Györkös, Becker, de Bruin, and Rossier (2015), in their study of migrant employees, discussed the relationship between different age groups and job stress. They said that, like our study, the 18 to 29 age group, in particular, showed a higher level of job stress than the one for older employees. Matt and Dean (1993), however, found that the effect of distress was twice as great in a sample of older persons than a sample of younger persons. According to Law et al. (1995), there was no significant difference between the source of stress and the age of respondents. Hunnur and Bagali (2014) also found that stress dimensions did not differ significantly by age. According to test statistics, Factor 1 differed statistically between (at least two) different tenure groups. Ross (1997) said that work stress has the potential to affect the performance of all levels of staff, ranging from senior management to the young and newly employed. Elkahlout and Algaed (2003) indicated that years of experience had no effect on job stress levels. Klassen and Chiu (2010) emphasized the relationship between years of experience and job stress. Consistent with our findings, Hunnur and Bagali (2014) proposed that stress dimensions do not differ by job tenure. However, Baytar's study (2010) argued that all the stress factors differ by different levels of tenure. Respondents of the study working in different departments evaluated factors 1 and 3 differently. Elkahlout and Algaed (2003) said that there is no significant difference between departments regarding answers to job stress questions. Hwang et al. (2013) mentioned "department" as an effective demographic variable on defining job stress. They said that respondents who worked in the departments of "food and beverage" and "housekeeping" carried more stress from problems related to home life. The results of the study pertaining to the differences between educational level and stress factors were revealed in factors 2 and 4, which had mean scores that differed statistically between (at least two) educational levels. Elkahlout and Algaed (2003) proposed that there is a significant difference between educational level and job stress level.

However, Baytar (2010) found no statistical difference between stress factors and different education levels. In parallel with him, Hunnur and Bagali (2014) revealed that stress-causing dimensions did not differ drastically between graduates and undergraduates. While they did not address stress factors, De Smet et al. (2005) found a lower prevalence of strain in more educated employees of both genders. 
Hotel jobs are demanding and there are many sources of job stress. Hotel management cannot ignore this issue, and although encouraging employees to develop self-mechanisms to handle stress is important, hotels must also consider different ways to assist employees with stress management (Wong and Huang, 2014). In hotel management, identifying and managing the factors of employee comfort and satisfaction are important, in order to increase their performance and manage them effectively. As this study investigated the differences between stress factors affecting hotel employees and demographic variables, the results can be used to better understand job stress of employees in the tourism industry, especially for the Turkish hotel industry. Moreover, these findings will be useful for hotel managers as they plan and develop their strategies for stress management. Hotels should organize stressmanagement training programs to enable employees to cope with occupational stress. By understanding the stress factors and their relationship with demographic factors, hotel managers can eliminate (or at least alleviate) stress in the work environment. These strategies will improve employee performance; better employee performance will benefit their organizations. It should not be forgotten that a happy team can be remarkably profitable for an hotel. Some potential limitations of this study should be noted. This is because the data were collected from convenient samples of employees at four- and five-star hotels in Istanbul, the limited sample framework and size might be seen as a drawback. Thus, further studies should be carried out using larger samples from more hotels and from more geographically diverse parts of Turkey. The study also placed a limited focus on the differences between demographic variables and stress factors. Accordingly, future studies should further investigate the impacts of stress factors or, perhaps, the relations between stress, performance, and turnover intention.

\section{References}

AbuAlRub, R. F. (2004). Job stress, job performance and social support among hospital nurses. Journal of Nursing Scholarship, 36(91), 73-78.

Abramis, D.J. (1994), "Relationship of job stressors to job performance: linear or an inverted-U?”, Psychological Report, Vol. 75 No. 1, p. 547.

Agyemang, C. B., \& Arkorful, H. K. (2013). Influence of demographic factors on job stress and job satisfaction among custom officials in Ghana. Research on Humanities and Social Sciences, 3(16), 37-45.

Ağaoğlu, O. K. (1992). İşgücünü verimli kullanma tekniklerinin turizm sektörüne uygulanmas1. Verimlilik Dergisi, 110-121.

Ashton, A. S. (2017). How human resources management best practice influence employee satisfaction and job retention in the Thai hotel industry. Journal of Human Resources in Hospitality \& Tourism, 1-25.

Baytar, Ö. (2010). İş Yaşamında Stresin İş gören Performansı Üzerindeki Etkileri.

Beehr, T.A., Jex, S.M., Stacy, B.A., Murray, M.A., 2000. Work stressors and coworker support as predictors of individual strain and job performance. Journal of Organizational Behavior, 21 (4), 391-403. 
Brewer, E., and McMahan-Landers, J. (2003). The relationship between job stress and job satisfaction among industrial and technical teacher educators. Journal of Career and Technical Education, 20(1), 37-50.

Chiang, C. F., \& Liu, B. Z. (2017). Examining job stress and burnout of hotel room attendants: internal marketing and organizational commitment as moderators. Journal of Human Resources in Hospitality \& Tourism, 16(4), 367-383.

Chiang, F. F., Birtch, T. A., and Kwan, H. K. (2010). The moderating roles of job control and work-life balance practices on employee stress in the hotel and catering industry. International Journal of Hospitality Management, 29(1), 25-32.

Chuang, N. K., and Lei, S. A. (2011). Job stress among casino hotel chefs in a top-tier tourism city. Journal of Hospitality Marketing and Management, 20(5), 551-574.

Chusmir, L.H. and Franks, V. (1988). Stress and the woman manager. Training and Development Journal, 10(1), 66-70.

Cleveland, J., O’Neill J., Himelright, J., Harrison, M., Crouter, A., and Drago, R. (2007). Work and family issues in the hospitality industry: perspectives of entrants, managers and spouses. Journal of Hospitality and Tourism Research, 31(3), 275-298.

Çokluk, Ö., Şekercioğlu, G., \& Büyüköztürk, Ş. (2014). Sosyal bilimler için çok değişkenli istatistik: SPSS ve LISREL Uygulamaları (3th ed.). Ankara: Pegem Akademi.

Cooper, C. L., and Marshall, J. (1976). Occupational sources of stress: Review of literature relating to coronary heart disease and mental ill health. Journal of Occupational Psychology, 49(1), 11-28.

Cooper, C. L., Rout, U., and Faragher, B. (1989). Mental health, job satisfaction, and job stress among general practitioners. BMJ, 298(6670), 366-370.

Cozens, J. (1998). Individual and organizational predictors of depression in general practitioners. British Journal of General Practice, 48(435), 1647-1651.

Dewe, P. and Trenberth, L. (2004). Work stress and coping: Drawing together theory and practice. British Journal of Guidance and Counselling, 32, pp. 143-156.

Danziger, E. (1988). Minimize office gossip. Personnel Journal, 67, 31-34

De Smet, P., Sans, S., Dramaix, M., Boulenguez, C., De Backer, G., Ferrario, M., Kornitzer, M. (2005). Gender and regional differences in perceived job stress across Europe. The European Journal of Public Health, 15(5), 536-545.

Elkahlout, G. R., \& Algaed, A. O. (2003). The effect of some socio-demographic factors on job stress level in nursing work. Umm Al-Qura University Journal of Educational and Social Sciences and Humanities, 15(1), 34-53.

Ellwardt, L., Labianca, G., and Wittek, R. (2012). Who are the objects of positive and negative gossip at work? A social network perspective on workplace gossip. Social Networks, 34, 193-205. http://dx.doi.org/10.1016/j.socnet.2011.11.003 
Essawy, M. (2016). Job stressors, emotional exhaustion and service recovery in independent quick service restaurants in Egypt: an empirical investigation. Advances in Hospitality and Tourism Research, 4(1), 1-16.

Faulkner, B., and Patiar, A. (1997). Workplace induced stress among operational staff in the hotel industry. International Journal of Hospitality Management, 16(1), 99117.

Gaillard, A. W. K. (2001). Stress, workload, and fatigue as three bio behavioral states: A general overview. In P.A. Hancock, and P.A. Desmond (Eds.), Stress, Workload, and Fatigue. Mahwah, NJ: L. Erlbaum.

Georganta, K., Panagopoulou, E., and Montgomery, A. (2014). Talking behind their backs: Negative gossip and burnout in Hospitals. Burnout Research, 1(2), 76-81.

Gibson, J. L., Ivancevich, J. M., Donnelly, J. H. and Konopaske, R. (2006). Organizations: Behavior, Structure, Processes (12th Ed.). McGraw-Hill: Irwin Boston.

Gilboa, S., Shirom, A., Fried, Y., \& Cooper, C. (2008). A meta-analysis of work demand stressors and job performance: examining main and moderating effects. Personnel Psychology, 61(2), 227-271.

Golbasi, Z., Kelleci, M., and Dogan, S. (2008). Relationships between coping strategies, individual characteristics and job satisfaction in a sample of hospital nurses: Cross-sectional questionnaire survey. International Journal of Nursing Studies, $45,1800-1806$.

Gupta, N., Beeher, T.A., 1979. Job stress and employee behaviours. Organizational Behaviour and Human Performance, 23 (3), 373-385.

Hayes, C. T., \& Weathington, B. L. (2007). Optimism, stress, life satisfaction, and job burnout in restaurant managers. The Journal of psychology, 141(6), 565-579.

Hof, M. (2012). Questionnaire evaluation with factor analysis and Cronbach's alpha: an example.

Hunnur, S. R. R., and Bagali, M. M. (2014). A study on relationship between occupation stress index dimensions and demographic variables of police sub inspectors and asst. Sub inspectors in police department. Psychology, 13(3), 283284.

Hwang, J., Hyun, S. S., \& Park, J. (2013). Segmentation of hotel employees by occupational stress and differences in demographic characteristics. Asia Pacific Journal of Tourism Research, 18(3), 241-261.

Hwang, J., Lee, J. J., Park, S., Chang, H., and Kim, S. S. (2014). The Impact of Occupational Stress on Employee's Turnover Intention in the Luxury Hotel Segment. International Journal of Hospitality and Tourism Administration, 15(1), 60-77.

Ismail, A., Yao, A., and Yunus, N. K. Y. (2009). Relationship between occupational stress and job satisfaction: An empirical study in Malaysia. The Romanian Economic Journal, 13(34), 3-29. 
Ismail, A., Mohamed, H.A., Sulaiman, A.Z., Ismail, Z., and Wan Mahmood, W.N. (2010). Relationship between work stress, coworker's social support, work stress and work interference with family conflict: An empirical study in Malaysia. International Business Management, 4(2), 76-83.

Ivancevich, J.M., and Matteson, M.T. (1980), Stress and Work: A Managerial Perspective, Glenview IL: Scott, Foresman and Co.

Jamal, M. (1990). Jacks of all trades. Hotel and Motel Management, 212(3), 22-24.

Jamal, M., and Baba, V. (2000). Job stress and burnout among Canadian managers and nurses: an empirical examination. Canadian Journal of Public Health, 91(6), 454-459.

Kaya, M. (2013). The effects of percelved organızatıonal justıce on police job satısfaction, job involvement and job stress: A case of a Turkish natıonal police. (A dissertation of Doctor of Education in Leadership Education). Spalding University, USA

Kessler, R. C. (1979). Stress, social status, and psychological distress. Journal of Health and Social behavior, 259-272.

Kim, D. H., Lee, Y. H., and Lee, J. W. (2008). Assessment of job stress factors and organizational personality types for procedure-based jobs in nuclear power plants. Journal of nuclear science and technology, 45(8), 784-792.

Kim, H. J., Shin, K. H., \& Umbreit, W. T. (2007). Hotel job burnout: The role of personality characteristics. International Journal of Hospitality Management, 26(2), 421-434.

Klassen, R. M., and Chiu, M. M. (2010). Effects on teachers' self-efficacy and job satisfaction: Teacher gender, years of experience, and job stress. Journal of educational Psychology, 102(3), 741.

Koc, E., \& Bozkurt, G. A. (2017). Hospitality Employees' Future Expectations: Dissatisfaction, Stress, and Burnout. International Journal of Hospitality \& Tourism Administration, 18(4), 459-473.

Krone, C., Tabacchi, M. and Faber, B. (1988), "Manager burnout", Cornell Quarterly, Vol. 30, pp. 58-63.

Kurland, N. B., and Pelled, L. H. (2000). Passing the word: Toward a model of gossip and power in the workplace. Academy of Management Review, 25(2), 428-438.

Lambert, E. G., Minor, K. I., Wells, J. B., \& Hogan, N. L. (2016). Social support's relationship to correctional staff job stress, job involvement, job satisfaction, and organizational commitment. The Social Science Journal, 53(1), 22-32.

Larson, L.L. (2004). Internal auditors and job stress. Managerial Auditing Journal, 19(9), 1119-1130.

Law, J., Pearce, P. L., \& Woods, B. A. (1995). Stress and coping in tourist attraction employees. Tourism Management, 16(4), 277-284.

Lazarus, R. S. (1993). From psychological stress to the emotions: A history of changing outlooks. Annual Review of Psychology, 44, 1-21. doi 10.1146/annurev.ps.44.020193.000245 
LePine, J. A., Podsakoff, N. P., \& LePine, M. A. (2005). A meta-analytic test of the challenge stressor-hindrance stressor framework: An explanation for inconsistent relationships among stressors and performance. Academy of Management Journal, 48(5), 764-775.

Leung, M. Y., Shan Isabelle Chan, Y., and Dongyu, C. (2011). Structural linear relationships between job stress, burnout, physiological stress, and performance of construction project managers. Engineering, Construction and Architectural Management, 18(3), 312-328.

Loewen, S., \& Gonulal, T. (2015). Exploratory factor analysis and principal components analysis. Advancing quantitative methods in second language research, 182-212.

Marwick, K. P. (1991). The Tourism Labour Market-Constraints and Attitudes. Sydney: Tourism Training Australia.

Mansour, S., \& Mohanna, D. (2017). Mediating role of job stress between work-family conflict, work-leisure conflict, and employees' perception of service quality in the hotel industry in France. Journal of Human Resources in Hospitality \& Tourism, $1-21$.

Mathur, G., Vigg, S., Sandhar, S., \& Holani, U. (2007). Stress as a correlate of job performance: a study of manufacturing organizations. Journal of Advances in Management Research, 4(2), 79-85.

Matt, G. E., and Dean, A. (1993). Social support from friends and psychological distress among elderly persons: Moderator effects of age. Journal of Health and Social Behavior, 187-200.

McFillen, J. M., Riegel, C. D., \& Enz, C. A. (1986). Why restaurant managers quit (and how to keep them). Cornell Hotel and Restaurant Administration Quarterly, 27(3), 36-43.

Michelson, G., and Mouly, V. S. (2000). Rumor and gossip in organizations: A conceptual study. Management Decision, 38, 339-346.

Motowidlo, S. J., Packard, J. S., \& Manning, M. R. (1986). Occupational stress: its causes and consequences for job performance. Journal of applied psychology, $71(4), 618$.

Murray-Gibbons, R., and Gibbons, C. (2007). Occupational stress in the chef profession. International Journal of Contemporary Hospitality Management, 19(1), 32-42.

Murphy, L.R. (1995), Managing job stress: an employee assistance/human resource management partnership. Personnel Review, 24 (1), 41-50.

Okutan, M., and Tengilimoğlu, D. (2002). İş ortamında stres ve stresle başa çıkma yöntemleri: Bir alan uygulaması. İktisadi ve İdari Bilimler Fakültesi Dergisi, 4(3), $1-27$.

O'neill, J. W., \& Davis, K. (2011). Work stress and well-being in the hotel industry. International journal of hospitality management, 30(2), 385-390. 
Papadopoulou-Bayliss, A., Ineson, E. M., \& Wilkie, D. (2001). Control and role conflict in food service providers. International Journal of Hospitality Management, 20(2), 187-199.

Pocnet, C., Antonietti, J. P., Massoudi, K., Györkös, C., Becker, J., de Bruin, G. P., and Rossier, J. (2015). Influence of Individual Characteristics on Work Engagement and Job Stress in a Sample of National and Foreign Workers in Switzerland. Swiss Journal of Psychology/Schweizerische Zeitschrift für Psychologie/Revue Suisse de Psychologie.

Preston, D. B. (1995). Marital status, gender roles, stress, and health in the elderly. Health Care for Women International, 16(2), 149-165.

Quick, J. C., and Quick, J. D. (1984). Organization stress and preventive management. New York, NY: McGraw-Hill.

Ramirez, A. J., Graham, J., Richards, M. A., Gregory, W. M., \& Cull, A. (1996). Mental health of hospital consultants: the effects of stress and satisfaction at work. The Lancet, 347(9003), 724-728.

Robbins, S.P. (2003). Organizational Behavior (10th Ed.). Prentice Hall, NJ. doi: 9780131025417

Ross, G. F. (1993). Type, severity and incidence of work stressors among Australian hospitality industry employees. Australian Journal of Leisure and Recreation, 3(4), 5-12.

Ross, G. F. (1995). Work stress and personality measures among hospitality industry employees. International Journal of Contemporary Hospitality Management, 7(6), 9-13.

Ross, G. F. (1997). Career stress responses among hospitality employees. Annals of Tourism Research, 24(1), 41-51.

Rothmann, S., Jackson, L.T.B., Kruger, M.M., (2003). Burnout and job stress in a local government: the moderating effect of sense of coherence. SA Journal of Industrial Psychology. 29(4), 52-60

Schabracq, M.J. and Cooper, C.L. (2000). The changing nature of work and stress. Journal of Managerial Psychology, 15(3), 227-42.

Schuler, R. S. (1982). An integrative transactional process model of stress in organizations. Journal of Organizational Behavior, 3(1), 5-19.

Savery, L., and Luks, J. (2001). The relationship between empowerment, job satisfaction and reported stress levels. Journal of Leadership and Organization Development, 22(3), 97-105.

Sullivan, S. E. and Bhagat, R. S. (1992). Organizational stress, job satisfaction and job performance: where do we go from here? Journal of Management, $18 \mathrm{c}$ (2), 35374.

Sunny'Hu, H. H., and Cheng, C. W. (2010). Job stress, coping strategies, and burnout among hotel industry supervisors in Taiwan. The International Journal of Human Resource Management, 21(8), 1337-1350. 
Sutton, R. I., and Rafaeli, A. (1987). Characteristics of work stations as potential occupational stressors. Academy of Management Journal, 30(2), 260-276.

Thoits, P. A. (1987). Gender and marital status differences in control and distress: Common stress versus unique stress explanations. Journal of Health and Social Behaviour, 7-22.

Torkelson, E., Muhonen, T., and Peiró, J. (2007). Constructions of work stress and coping in a female-and a male-dominated department. Scandinavian Journal of Psychology, 48(3), 261-270.

Tsaur, S. H., \& Tang, Y. Y. (2012). Job stress and well-being of female employees in hospitality: The role of regulatory leisure coping styles. International Journal of Hospitality Management, 31(4), 1038-1044.

Uslu, B. (2016). Managerial flexibility regarding scholarly practices scale: Validity and reliability studies in university environment. Kuram ve Uygulamada Ĕ̈itim Yönetimi, 22(1), 109-131.

Vanagas, G., Bihari-Axelsson, S., and Vanagiene, V. (2004). Do age, gender and marital status influence job strain development for general practitioner? Medicina (Kaunas), 40(10), 1014-1018.

Vakola, M., and Nikolaou, I. (2005). Attitudes towards organizational change: What is the role of employees' stress and commitment? Employee relations, 27(2), 160174.

Varca, P. E. (1999). Work stress and customer service delivery. Journal of Services Marketing, 13(3), 229-241.

Westman, M., Etzion, D. (2001). The impact of vacation and job stress on burnout and absenteeism. Psychology and Health. 16(5), 595-606

Wildes, V. J. (2007). Attracting and retaining food servers: How internal service quality moderates occupational stigma. International Journal of Hospitality Management, 26(1), 4-19.

Wilnefield, H. R., and Anstey, T. J. (1991). Job stress in general practice: practitioner age, sex and attitudes as predictors. Family Practice, 8(2), 140-144.

Wong, S. C. K., and Ko, A. (2009). Exploratory study of understanding hotel employees' perception on work-life balance issues. International Journal of Hospitality Management, 28(2), 195-203.

Wong, S. C. K., and Huang, C. Y. (2014). A Factor-Cluster Approach to Understanding Hong Kong Hotel Employees' Symptom-management-related Coping Behavior Towards Job Stress. Asia Pacific Journal of tourism Research, 19(4), 469-491.

Woodruff, L. (1993). Occupational stress for correctional personnel. American Jails, 7(5), 71-72.

Zohar, D. (1994). Analysis of job stress profile in the hotel industry. International Journal of Hospitality Management, 13(3), 219-231. 